\title{
Farmer's Awareness on Effective Delivery of Farm Information through ICT Mediated Extension Service in Bangladesh
}

\section{Sadia Jahan Moon}

Department of Environment and Development Studies, Norwegian University of Life Sciences, Norway

\section{Abdul Momen Miah}

Professor, Department of Agricultural Extension Education, Bangladesh Agricultural University, Mymensingh, Bangladesh

\section{Trygve Berg}

Department of Environment and Development Studies, Norwegian University of Life Sciences, Norway

doi: 10.19044/esj.2016.v12n21p9 URL:http://dx.doi.org/10.19044/esj.2016.v12n21p9

\section{Abstract}

The main focus of the study was to find out the level of awareness about effective delivery of farm information to the farmers through ICT mediated extension service in Bangladesh. The factors influencing awareness of the farmers and the problems faced by the farmers in getting farm information were also explored. Data were collected from a sample of 100 farmers out of 700. A structured interview schedule and check list were used in collection of data through face to face interviewing and focus group discussion (FGD) during October to November in 2012. The awareness was measured by using a 3 point rating scale and appropriate weights were assigned to each of the responses. By adding the weights of responses awareness score was calculated. The effectiveness of ICT mediated extension services was considered based on amount of information being supplied, acceptability, diversity, demand driven and outcome in using information by the farmers. About two-thirds (68 percent) of the farmers had moderate awareness while almost one fourth (26 percent) having high and only 6 percent had low awareness about effective delivery of farm information by ICT centers. The level of education, farm size, family size, annual income, training exposure, organizational participation and extension media contact of the farmers were significantly correlated with their awareness. The stepwise multiple regression analysis showed that out of 9, four variables such as organizational participation, annual income, farm size and family size of the farmers combinedly explain 50 percent variance regarding 
awareness of effective delivery of farm information. Rendering inadequate services of field extension agents, frequent power disruption, lack of skilled manpower (extension agents) at ICT centers, lack of training facilities for the farmers, and poor supervision and monitoring of field extension activities were the major problems as mentioned by the farmers for effective dissemination of farm information.

Keywords: Awareness, ICT, extension service, effective delivery, farmer

\section{Introduction}

The information and communication technology (ICT) plays a vital role in all spheres of social, economic, and political aspects of development process. It rapidly is changing living styles and livelihoods by creating opportunities of wide job markets in local, regional, national and international levels. It increases access to information for large section of the population which in turn enhances development process.

Bangladesh since independence has been trying to increase food production for feeding its increasing population. In doing so, it has been changing its extension strategy from time to time in modernizing farming systems for increasing food production. In addition, efforts have been made by various development partners and donor agencies towards ensuring food security of the population.

"Agricultural extension services in the country provide critical access to the knowledge, information and technology that farmers require to improve the productivity and thus improve the quality of their lives and livelihoods. It is hence crucial to provide farmers with the knowledge and information in a quality and timely way. Although some ground breaking tools like the telecenters can serve as major catalysts for information, knowledge and development opportunities, the access for the farmers in remote villages is restricted due to the lack of infrastructure" (UN, 2005). Kaushik and Singh (2004) found that ICT allows efficient and transparent storage, processing and communication of farm information and the entrepreneurial innovation in this field may affect economic and social change. In addition Kraemer and Dedrick (1994) found growth in ICT investment is positively associated with growth in both GDP and productivity in Asia-Pacific countries during the period of 1984-1990.

Selwyn (2002) defined information and communication technology (ICT) as an umbrella term that includes computer hardware and software, digital broadcast and telecommunications technologies as well as digital information repositories online or offline, and includes contemporary social networking aspects, read/write interfaces on the web besides file sharing systems online. The author also found that ICT represents a range of 
elements which includes Television (TV), radio, mobile phones, and policies and laws that govern the widespread use of these media and devices. The ICTs in extension can lead to the emergence of knowledge workers that will result in the realization of a bottom-up, demand-driven paradigm for technology generation, assessment, refinement and transfer (Meera, 2003; Meera at al 2004).

Cowder (1998) explains role of ICT in development communication as a means to:

- $\quad$ bridge the communication gaps among development workers, rural organizations and farmers;

- $\quad$ foster new alliances and communication networks;

- $\quad$ enable bottom-up articulation of needs and information sharing of local knowledge;

- $\quad$ enhance relevance of agricultural research and extension; and

- $\quad$ improve the quality of decisions that affect rural communities and agricultural and rural development organizations.

In Bangladesh, during 2009 - 2010 agricultural information and communication center (AICC) was established with a view to prompt delivery of farm information to the farmers. Under the financial support of UNDP, DANIDA and FAO presently 145-150 AICCs are working at rural areas. In addition, Government has undertaken an ambitious project named A2i under which gradually an ICT center has been established in each Union Parishad. The main purpose of theses centers is to digitalization of all development activities including agriculture. Accordingly Bangladesh Agricultural University Extension Center (BAUEC), BAU has establishes 5 ICT centers in its working areas to ensure timely supply of information to BAUEC beneficiary farmers. After two years of using ICT mediated extension service it was felt that it is necessary to find out the level of awareness of the farmers about effectiveness of ICT in extension work.

\section{Objectives}

The following objectives are formulated in conducting the study:

1. To asses the level of awareness of the farmers towards the effective delivery of farm information through ICT mediated extension system.

2. To describe some of the selected characteristics of the farmers. The characteristics are age, level of education, farm size, family size, farming experience, annual income, organizational participation, training exposure and extension media contact.

3. To measure relationship between selected characteristics of the farmers and their awareness about effective delivery of farm information through ICT. 
4. To identify the major problems encountered by the farmers in getting information from ICT centers.

\section{Methodology}

The 5 ICT centers of BAUEC have been operating since 2010 under Mymensingh district was the locale of the study. One hundred farmers from 5 ICT centers under BAUEC were selected randomly from a total population of 700. A structured questionnaire and a check list were used to collect data from the farmers. The data was collected during May to June 2012 from the sample. In addition, FGD was conducted with a group of 16 farmers for supplementing the collected data.

Awareness is an understanding of an individual about something. Awareness of the farmers regarding the effective delivery of farm information by using ICT based extension service was the dependent variable of the study. The farmers were asked to give their opinion on 15 specific roles of ICT, which were identified through discussion with different stakeholders before and during pre-testing of data collection instruments. A 3- point rating scale was used to measure the extent of awareness of the farmers. Appropriate weights such as 2 for 'fully aware', 1 for 'partially aware' and 0 for 'not aware' was assigned to each of the scale to measure the level of awareness of the farmers. By adding the assigned weights of each of the responses under 15 specific roles together, the awareness of a farmer on effective delivery of farm information through ICT was measured.

The age and farming experience of the farmers were measured in actual years, level of education by number of years of schooling of the respondents, and family size by number of family members ate together and share resources. The farm size was determined in terms of area of land under possession of the family and expressed in hectare. The classification of farm size of the farmers was made based on DAE manual (1999). The training exposure was calculated by receiving training by the respondent during farming career on farming activities in number of days. The money earned by a farmer and his family members during preceding year of data collection was considered as annual income of the respondent. The organizational participation and extension media contact of the farmers were calculated by using appropriate scales. The statistical measures such as range, frequency, number, percentage, mean, standard deviation (SD) and rank order were used for interpretation of data. The inferential statistics such as Pearson's product moment correlation coefficient (r), step wise regression analyses were conducted for interpretation of findings. The degree of freedom (df) of the study was $n-2=100-2=98$ and the table value of $r=0.196$ at $5 \%$ level of probability. 


\section{Results and discussion}

\section{Awareness about ICT}

The awareness score of the farmers about effective delivery of information through ICT ranged from 10 to 25 against the possible range of 0 to 30 . The mean value was 18.06 and standard deviation being 2.957. The farmers were classified into three categories on the basis of their awareness score and presented in Table 1.

The information of Table 1 indicates that about one-fourth of the farmers had high awareness about ICT mediated extension service while 68 percent having medium and only 6 percent were poorly aware about effectiveness of ICT based extension system. Almost similar trend of awareness of farmers on environmental degradation was reported by Hossain at. el. (2003) while Khan at .el. (2003) found different findings. This means 94 percent of the farmers were aware about effectiveness of ICT based information delivery system. This may be due to massive propaganda from government as well as NGOs about digitalization of development activities in general and agriculture in practical.

The farmers opined that updated, need based, demand driven and diversified information is available from ICT. The ICT also provide farmers a wide range of options in solving both simple and complicated farming problems. For solving emergency needs it is effective in quick delivery of farm information. It is easier to make correct diagnosis of farming problems by both the farmers and extension agents because of its well organized presentation. Finally, it can be said that the ICT was found more effective in dissemination of farm information to the farmers.

\section{Characteristic profile of the farmers}

Nine demographic characteristics of the farmers were studied and presented in Table 2.

The information of Table 2 shows that a large majority (82 percent) of the farmers were middle aged and similarly 79 percent having varying extent of level of education. Less than one fourth of the respondents had small family while the rest having medium to large family. Only 3 percent of the respondents were large farmers while a vast majority (90 percent) was resource-poor farmers. Sixty eight percent of the farmers have a good amount of farming experience and the rest were low experienced. Nine out of 10 farmers fell in medium to high income group and the rest of them have low annual income. About two-thirds of the farmers have medium to high training exposure on the contrary more than three-fourths having low organizational involvement, Miah at. el., (2000) found almost similar organizational participation of women. A large number (94 percent) of the farmers maintained medium to high contact with information media for 
getting farm information.

\section{Relationship between dependent \& independent the variables}

Level of awareness of the farmers about effective delivery of farm information was the dependent variable while 9 selected characteristics of the respondents were the independent variables of the study. The relationships between the variables are presented in Table 3.

All the independent variables were found significantly correlated with the level of awareness with varying extent except age and farming experience of the farmers. This means most of the personal characteristics have a significant amount of influence in creating awareness among the farmers towards effective delivery of farm information through ICT based extension system. In order to find out the relative contribution of independent variables on farmers' awareness towards effectiveness of ICT, step wise regression analyses was computed and presented in Table 4.

As Theil (1978) mentioned that it is good to practice adjusted $\mathrm{R}^{2}$ rather than $\mathrm{R}^{2}$ beaucse $\mathrm{R}^{2}$ trends to givean overly optimistic picture of the fit of the regression, particularly when the number of explanatory variables is not very small compared with the number of observations. So, the adjusted $\mathrm{R}^{2}$ indicate that organizational participation, annual income, farm size and family size of the farmers have explained 47.9 percent of the variation of the relationship. It is evident from the model that the farmers who have more participation in organizations, higher income, farm size and larger family found to have positive contribution in building awareness towards effective delivery of farm information through ICT based extension system. The organizational participation enables the farmers to have better exposure and interaction with other members of the social system increases awareness of the farmers. The more the farm size, higher annual income and extra family labor of the farmers contribute positively towards the formation of awareness.

\section{Problem confrontation}

The problems confronted by the farmers in getting benefit from the local ICT centers were identified and presented in Table 5. The number of citations made by the farmers indicates the intensity of the problems.

The information of Table 5 shows that the major problems faced by the farmers in getting extension services through ICT were inadequate field activities of grass root level extension agents, lack of skilled extension agents in ICT, often failure of ICT network due to frequent power disruption and poor monitoring of field activities were the major problems. Appropriate steps from the concerned organizations such as DAE, PDB, local government bodies and NGOs working with farmers about farming could 
undertake steps in minimizing the problems.

\section{Conclusion and recommendations}

The level of awareness of the farmers about effective delivery of farm information through ICT was found positive and encouraging. Inadequate monitoring and supervision of ICT activities along with frequent power failure at rural areas hampered the harvesting of reasonable benefit of ICT in agriculture. The capacity building of both extension agents and the innovative farmers towards use of ICTs could strengthen the dissemination of farm information to the farmers. The motivation campaign and capacity building of extension agents as well as the farmers could speed up the information delivery system.

\section{References:}

Crowder, L.V. (1998). Knowledge and Information for Food Security-The Role of Telecentres. Seminar on Multipurpose Community Telecentres, Budapest, 7-9 December 1998. PP.2-9.

Hossain, M.A., Suttradhar, N.C., Kashem, M.A \& Sarker, M.A. (2003). Farmers' Awareness on Environmental Degradation caused by the use of Modern Agricultural Technologies. Bangladesh Journal of Extension Education, Vo. 15, No.1\&2, Bangladesh Agricultural Extension Society, BAU, Mymensingh. PP.41-46.

Kaushik, P.D. \& Singh, N. (2004). Information Technology and Broad-Based Development: Preliminary Lessons from North India. World Development, PP.32, 591-607.

Khan, M.M.A., Rahman, M.H. \& Rahman, M.Z. (2003). Farmers'Awareness on Adverse Effects of Rice Monoculture. Bangladesh Journal of Extension Education, Vo. 15, No.1\&2, Bangladesh Agricultural Extension Society, BAU, Mymensingh. PP.109-116.

Meera, S.N. (2003). A critical analysis of information technology in agricultural development: impact and implications. Unpublished PhD thesis, IARI, New Delhi.

Meera, S.N., Jhamtani, A. \&. Rao, D.U.M. (2004). Information and communication technology in agricultural development: a comparative analysis of three projects from India. Ag REN Network Paper No. 135, ODI, January 2004.20p.

Miah, M.A.M., Almin, S. \& Islam, M.M. (2000). Communication Exposure of the Farm Women in Receiving Homestead Farming Information. Bangladesh Journal of Agricultural Sciences, Vol. 27 no.2 BangladshAgricultural University old Boy's Association, BAU, Mymensingh. PP.217-223. 
Selwyn, N. (2002). Defining the ÔDigital DivideÕ: developing a theoretical understanding of inequalities in the information age. Available at: http://www.cf.ac.uk/socsi/ict/definigdigitaldivide.pdf.

Henri Theil, Introduction to Economics, Prentice-Hall, Inc., Englewood Cliffs, N.J., 1978, p. 135.

Table1: Awareness of the farmers regarding role of ICT in delivery of farm information

\begin{tabular}{|c|c|c|c|c|}
\hline \multirow{2}{*}{ Categories of awareness } & \multicolumn{2}{|c|}{ Farmers } & \multirow{2}{*}{ Mean } & $\begin{array}{c}\text { Standard } \\
\text { deviation }\end{array}$ \\
\cline { 2 - 3 } & Number & Percent & & \\
\hline Low (up to 10) & 6 & 6 & & \\
\hline Medium (11-20) & 68 & 68 & \multirow{2}{*}{18.06} & 2.957 \\
\hline High (above 20) & 26 & 26 & & \\
\hline Total & 100 & 100 & & \\
\hline
\end{tabular}

Table 2: Characteristic profile of the farmers

\begin{tabular}{|c|c|c|c|c|c|c|c|}
\hline \multirow[t]{2}{*}{ Characteristics } & \multicolumn{2}{|c|}{ Score range } & \multirow[t]{2}{*}{ Categories } & \multicolumn{2}{|c|}{$\begin{array}{c}\text { Farmers } \\
\mathrm{N}=120\end{array}$} & \multirow[t]{2}{*}{ Mean } & \multirow[t]{2}{*}{ SD } \\
\hline & Possible & Observed & & No. & $\%$ & & \\
\hline Age & Actual Years & $26-62$ & $\begin{array}{c}\text { Young (up to 35) } \\
\text { Middle aged (36-50) } \\
\text { Old aged (above 50) }\end{array}$ & $\begin{array}{c}5.0 \\
82.0 \\
13.0\end{array}$ & $\begin{array}{c}5.0 \\
82.0 \\
13.0\end{array}$ & 48.27 & 6.02 \\
\hline Education & $\begin{array}{c}\text { Years of } \\
\text { schooling }\end{array}$ & $0.5-12$ & $\begin{array}{c}\text { Illiterate }(0) \\
\text { Can sign only (0.5) } \\
\text { Primary education (1-5) } \\
\text { Secondary education (6- } \\
\text { 10) } \\
\text { Higher education } \\
\text { (above10) }\end{array}$ & $\begin{array}{c}0.0 \\
21.0 \\
37.0 \\
41.0 \\
1.0\end{array}$ & $\begin{array}{c}0.0 \\
21.0 \\
37.0 \\
41.0 \\
1.0\end{array}$ & 4.99 & 2.77 \\
\hline Family Size & $\begin{array}{l}\text { No. of } \\
\text { members }\end{array}$ & $3-10$ & $\begin{array}{l}\text { Small (up to 4) } \\
\text { Medium (5-6) } \\
\text { Large (above 6) }\end{array}$ & $\begin{array}{l}24.0 \\
45.0 \\
31.0\end{array}$ & $\begin{array}{l}24.0 \\
45.0 \\
31.0\end{array}$ & 5.74 & 1.80 \\
\hline Farm size & Hectares & $0.20-3.68$ & $\begin{array}{c}\text { Marginal (0.20-0.40 ha) } \\
\text { Small (0.41-1.01 ha) } \\
\text { Medium (1.02-3.03 ha) } \\
\text { Large (above 3.04 ha) }\end{array}$ & $\begin{array}{c}67.0 \\
23.0 \\
7.0 \\
3.0 \\
\end{array}$ & $\begin{array}{c}67.0 \\
23.0 \\
7.0 \\
3.0 \\
\end{array}$ & 0.44 & 0.41 \\
\hline Farming experience & Actual Years & $2-21$ & $\begin{array}{l}\text { low (up to 10) } \\
\text { Medium (11-20) } \\
\text { High (above 20) }\end{array}$ & $\begin{array}{c}32.0 \\
64.0 \\
4.0 \\
\end{array}$ & $\begin{array}{c}32.0 \\
64.0 \\
4.0 \\
\end{array}$ & 12.04 & 4.85 \\
\hline $\begin{array}{l}\text { Annual } \\
\text { income }\end{array}$ & $00.0 \mathrm{TK}$ & 28-145 & $\begin{array}{c}\text { Low (up to 50) } \\
\text { Medium (51-100) } \\
\text { High (above 100) }\end{array}$ & $\begin{array}{c}10.0 \\
85.0 \\
5.0 \\
\end{array}$ & $\begin{array}{c}10.0 \\
85.0 \\
5.0 \\
\end{array}$ & 65.26 & 19.82 \\
\hline $\begin{array}{l}\text { Training } \\
\text { exposure }\end{array}$ & Days & $4-16$ & $\begin{array}{c}\text { Low (1-6) } \\
\text { Medium (7-13) } \\
\text { High (above 13) } \\
\end{array}$ & $\begin{array}{l}33.0 \\
61.0 \\
6.0 \\
\end{array}$ & $\begin{array}{l}33.0 \\
61.0 \\
6.0 \\
\end{array}$ & 8.23 & 2.86 \\
\hline $\begin{array}{l}\text { Organizational } \\
\text { participation }\end{array}$ & Score & $1-21$ & $\begin{array}{l}\text { Low (up to 10) } \\
\text { Medium (11-20) } \\
\text { High (above 20) }\end{array}$ & $\begin{array}{c}77.0 \\
19.0 \\
4.0 \\
\end{array}$ & $\begin{array}{c}77.0 \\
19.0 \\
4.0 \\
\end{array}$ & 6.56 & 4.79 \\
\hline $\begin{array}{l}\text { Extension media } \\
\text { Contact }\end{array}$ & Score & $4-36$ & $\begin{array}{c}\text { Low (up to 7) } \\
\text { Medium (8-16) } \\
\text { High (above 16) }\end{array}$ & $\begin{array}{c}6.0 \\
68.0 \\
26.0\end{array}$ & $\begin{array}{c}6.0 \\
68.0 \\
26.0 \\
\end{array}$ & 29.77 & 5.94 \\
\hline
\end{tabular}


Table 3: Relationship between the dependent and independent variables

\begin{tabular}{|c|c|c|}
\hline \multirow{2}{*}{ Dependent variable } & $\begin{array}{c}\text { Characteristics of farmers } \\
\text { (Independent variables) }\end{array}$ & Value of ' $\mathrm{r}$ ' \\
\hline \multirow{4}{*}{ Awareness about role of ICT } & Age & .116 \\
\cline { 2 - 3 } & Education & $.226^{*}$ \\
\cline { 2 - 3 } & Family size & $.339^{* *}$ \\
\cline { 2 - 3 } & Farm Size & $.402^{* *}$ \\
\cline { 2 - 3 } & Farming Experience & .079 \\
\cline { 2 - 3 } & Annual income & $.253^{* *}$ \\
\cline { 2 - 3 } & Training Exposure & $.593^{* *}$ \\
\cline { 2 - 3 } & Organizational Participation & $.201^{*}$ \\
\hline
\end{tabular}

Table 4: Step wise regression coefficients of the variables

\begin{tabular}{|c|c|c|c|c|}
\hline \multicolumn{5}{|c|}{ Model Summary } \\
\hline Model & $\mathrm{R}$ & $\mathrm{R}^{2}$ & Adjusted R & $\begin{array}{c}\text { Std. Error of the } \\
\text { Estimate }\end{array}$ \\
\hline 1. & $.593^{\mathrm{a}}$ & .351 & .345 & 2.393 \\
\hline 2. & $.654^{\mathrm{b}}$ & .428 & .416 & 2.259 \\
\hline 3. & $.683^{\mathrm{c}}$ & .466 & .450 & 2.194 \\
\hline 4. & $.707^{\mathrm{d}}$ & .500 & .479 & 2.134 \\
\hline \multicolumn{5}{|c|}{ a. Predictors: (Constant), Organizational participation } \\
\hline \multicolumn{5}{|c|}{ b. Predictors: (Constant), Organizational participation, Annual income } \\
\hline \multicolumn{4}{|c|}{ d. Predictors: (Constant), Organizational participation, Annual income, Farm size } \\
\hline
\end{tabular}

Table 5: Problems confronted by the farmers in getting information through ICT

\begin{tabular}{|c|c|c|}
\hline SL. No. & Problems & No. of citations \\
\hline 1. & Frequent power disruption & 26 \\
\hline 2. & Rendering inadequate services of field extension agents & 67 \\
\hline 3. & Lack of skilled manpower (extension agents) at ICT centers & 35 \\
\hline 4. & Lack of adjustment of office timing with the farmers & 11 \\
\hline 5. & Very often failure of ICT network & 31 \\
\hline 6. & $\begin{array}{c}\text { Irregular monitoring and supervision of field work by } \\
\text { supervisory officials of extension agency }\end{array}$ & 21 \\
\hline 7. & Lack of training facilities for the farmers on ICT & 10 \\
\hline
\end{tabular}

